\title{
Potrzeby polskiego sektora administracji publicznej a kształcenie prawnicze. Kilka uwag na tle zmian związanych z projektami „ustawy 2.0” oraz tzw. aplikacji uniwersyteckiej
}

\section{Streszczenie}

$\mathrm{W}$ artykule podjęto próbę zaprezentowania zmian legislacyjnych związanych z tzw. ustawą 2.0, tj. ustawą Prawo o szkolnictwie wyższym wraz z rozporządzeniem wykonawczym w sprawie studiów, jak i projektem tzw. aplikacji uniwersyteckiej, która aktualnie nie została jeszcze ujęta w jakiekolwiek ramy normatywne. Zmiany te mogą mieć wymierny wpływ na kształcenie prawnicze w Polsce, a co za tym idzie, także na sektor administracji publicznej w kontekście jego potrzeb. Wydaje się bowiem zasadne przyjęcie, że te dwa obszary badawcze, tj. sektor administracji publicznej i kształcenie prawnicze, są ze sobą wzajemnie powiązane jak i wzajemnie wpływające na siebie; administracja publiczna dla funkcjonowania potrzebuje bowiem kadr prawniczych, a te z kolei w wymierny sposób kształtują jej praktykę - przykładowo poprzez działalność naukową i wykładnię doktrynalną czy też sprawowanie nadzoru sądowego. Unikając przy tym odpowiedzi na pytania badawcze o charakterze generalnym, jak np. „jakie powinno być »dobre« kształcenie prawnicze?" czy też o optymalny model funkcjonalny administracji publicznej w Polsce, w tekście skupiono się w pierwszej kolejności na zarysowaniu postulatu tzw. dobrej administracji. W dalszej kolejności zaprezentowano wybrane zagadnienia z zakresu kształcenia prawniczego, które z taką administracją są związane i mogą służyć realizacji postulatu albo ją osłabiać. Zaprezentowano też założenia projektu aplikacji uniwersyteckiej oraz projekt ustawy wraz z rozporządzeniem wykonawczym. Zwrócono także uwagę na zjawisko mitologizowania kształcenia praktycznego, prezentując w tym zakresie pożądany kierunek działalności prawodawczej.

Słowa kluczowe: kształcenie prawnicze, prawo o szkolnictwie wyższym, administracja publiczna, aplikacja uniwersytecka

1 Dr Artur Kokoszkiewicz - Wyższa Szkoła Przedsiębiorczości i Administracji w Lublinie; e-mail: artur.kokoszkiewicz@gmail.com 


\title{
The Needs of the Polish Public Administration Sector versus Legal Education. Some Remarks on the Changes Relating to the Drafts of 'Act 2.0' and the 'University Apprenticeship'
}

\begin{abstract}
The article attempts to present the legislative changes relating to the so called Act 2.0, i.e, the law on higher education together with its implementary regulation on studies as well as the proposed university apprenticeship, which has not as of yet been made into law of any kind. These changes may have a considerable impact on legal education in Poland, and, hence, on the public administration sector in the context of its needs. For it seems justified to assume that the two research areas, i.e. the public administration sector and legal education are both interrelated and that they exert reciprocal influence upon each other. For public administration, in order to function properly, requires a supply of lawyers whereas the latter, in turn, considerably affects its practices - for instance, by way of academic activities and jurisprudential construction or judicial review. Avoiding addressing more general research questions, such as "What should 'good' legal education be like?" or about the optimal functional model of public administration in Poland, the text focuses, above all, on outlining the postulate of the so called good administration. Subsequently, selected issues are presented in the areas of legal education that are related to such administration and can serve to either implement the postulate or to weaken it. Presented are also the assumptions of the draft of the, so called, academic apprenticeship as well as the draft law together with its implementary regulation. Moreover, attention is paid to the phenomenon of mythologisation of practical education presenting a desired direction of legislative action in that respect.
\end{abstract}

Keywords: legal education, law on higher education, public administration, university apprenticeship 


\section{Wprowadzenie}

Z uwagi na trwający proces zmian legislacyjnych związanych z tzw. ustawą 2.0, tj. ustawą Prawo o szkolnictwie wyższym ${ }^{2}$, towarzyszącymi jej aktami niższego rzędu ${ }^{3}$ czy też projektami aktualnie nieujętymi w ramy projektu aktu normatywne$\mathrm{go}^{4}$, który to proces może mieć wymierny wpływ na kształcenie prawnicze w Polsce, uznałem za zasadne podjęcie próby naukowej refleksji nad tytułowym zagadnieniem potrzeb polskiego sektora administracji publicznej w kontekście zmian, jakie mogą zajść w kształceniu prawników. Przyjmuję przy tym założenia, że te dwa obszary badawcze, tj. sektor administracji publicznej i kształcenie prawnicze, są ze sobą wzajemnie powiązane jak i wzajemnie wpływające na siebie; administracja publiczna dla funkcjonowania potrzebuje bowiem kadr prawniczych, a te z kolei w wymierny sposób kształtują jej praktykę - przykładowo poprzez działalność naukową i wykładnię doktrynalną czy też sprawowanie nadzoru sądowego. Unikając przy tym odpowiedzi na pytania badawcze o charakterze generalnym, jak np. „jakie powinno być »dobre « kształcenie prawnicze?" czy też o optymalny model funkcjonalny administracji publicznej w Polsce - są to bowiem pytania na dysertacje, skupiam się $\mathrm{w}$ pierwszej kolejności na zarysowaniu postulatu tzw. dobrej administracji. W dalszej kolejności prezentuję wybrane zagadnienia z zakresu kształcenia prawniczego, które z taką administracją są związane i mogą służyć realizacji postulatu albo ją osłabiać. Prezentuję i oceniam założenia projektu tzw. aplikacji uniwersyteckiej oraz projekt u.p.s.w.in. wraz z rozporządzeniem wykonawczym. Poświęcam też uwagę zjawisku, które nazwałem mitologizowaniem kształcenia praktycznego, prezentując $\mathrm{w}$ tym zakresie pożądany kierunek działalności prawodawczej.

2 Projekt ustawy z dnia 3 lipca 2018 r. Prawo o szkolnictwie wyższym i nauce, opubl. na: http:// orka.sejm.gov.pl/opinie8.nsf/nazwa/2446_u/\$file/2446_u.pdf (dostęp: 19.07.2018), zwanej dalej ustawą albo u.p.s.w.in.

3 Projekt rozporządzenia Ministra Nauki i Szkolnictwa Wyższego z dnia 11 lipca 2018 r. w sprawie studiów, opubl. na: https://legislacja.rcl.gov.pl/docs/506/12313816/12521892/12521893/dokument349821.pdf (dostęp: 19.07.2018), zwany dalej rozporządzeniem.

4 Nieformalny projekt tzw. aplikacji uniwersyteckiej (akademickiej) dostępny wyłącznie w sferze publikacji publicystycznych i popularnonaukowych, szereg źródeł dotyczących projektu zaprezentuję w dalszej części tekstu. 


\section{Postulat dobrej administracji}

Kształcenie prawnicze, a w zasadzie dobre kształcenie prawnicze, przez które można rozumieć pożądany model kształcenia $\mathrm{w}$ tym zakresie chociażby z prakseologicznego punktu widzenia, jest nierozerwalnie związane $\mathrm{z}$ administracją publiczną. Ta bowiem dla funkcjonowania potrzebuje kadr rekrutujących się m.in. wśród osób z takim wykształceniem. Zarówno w doktrynie prawa, jak i jego praktyce, często mówi się o „dobrej administracji", przez którą w dużym uproszczeniu można by rozumieć pewne modelowe rozwiązanie cechujące się sprawnością i celowością funkcjonowania. W tym celu różne ośrodki decyzyjne podejmują różne działania ukierunkowane na osiągnięcie czy też chociażby zbliżenie się do tego celu. Przejawem takiej działalności jest w szczególności Europejski kodeks dobrej praktyki administracyjnej ${ }^{5}$ zawierający szereg zaleceń stanowiących swego rodzaju konkretyzację obywatelskiego prawa do dobrej administracji, wyrażonego w art. 41 Karty Praw Podstawowych Unii Europejskiej 6 . W kodeksie tym wskazano m.in. na zasadność funkcjonowania administracji w sposób praworządny, bezstronny, współmierny, uczciwy czy też na potrzebę udzielania porad w zakresie toczącego się postępowania. Natomiast „,W polskim porządku prawnym prawo do dobrej administracji nie zostało wyrażone expressis verbis $\mathrm{w}$ ramach najwyższego aktu prawnego w państwie, jakim jest Konstytucja Rzeczpospolitej Polskiej z 1997 r. [ani też w aktach niższego rzędu - przyp. A.K.]. Niezależnie od powyższego, na skutek dokonania wykładni, wyżej wymienione pojęcie można wywieść z zapisów konstytucyjnych (...), [w szczególności zaś z] art. 153 Konstytucji - odnoszącego się do administracji rządowej, ściślej korpusu służby cywilnej, stanowiącego o realizacji zadań państwa przez czteroelementowy charakter, mianowicie: zawodowy, rzetelny, bezstronny i politycznie neutralny"7. W piśmiennictwie podnosi się też, że z punktu widzenia dobrej administracji „istotne znaczenie ma również zasada proporcjonalności działań organów administracji publicznej. Przy tym aspekcie warto zwrócić uwagę, iż organ administracji publicznej, mając w swoich atrybutach element władztwa administracyjnego, powinien działać z rozsądnym ograniczeniem

5 Opubl. w Dz. Urz. UE C 2011.285.3. Zob. także publikację Europejskiego Rzecznika Praw Obywatelskich w tym zakresie: https://www.ombudsman.europa.eu/pl/resources/code.faces\#/ page/1 (dostęp: 20.07.2018).

6 Opubl.w Dz. Urz. UE C 2012.326.2.

$7 \quad$ P. Żuradzki, Prawo do dobrej administracji w polskim porzadku prawnym na tle Europejskiego kodeksu dobrej administracji, [w:] M. Kępa. M. Marszał (red.), Duch praw w krajach Europy Środkowo-Wschodniej, Wrocław 2016, s. 54. 
ingerencji w sferę praw jednostki" ${ }^{\prime}$. A zatem, aby móc realizować przytoczone zalecenia i zasady $w$ działalności administracji publicznej, która jest przecież $\mathrm{w}$ swojej funkcjonalnej istocie tworem kadrowym, niezbędne jest zapewnienie tejże administracji odpowiednio wykształconych pracowników, a w szczególności - prawników. Reasumując, istnieje związek pomiędzy potrzebami administracji publicznej a kształceniem prawniczym polegający m.in. na potrzebie zapewnienia kadr organom administracji oraz instytucjom związanym z administracją, jak np. sądy. Można postawić przy tym hipotezę, że im lepiej będą wykształcone (przygotowane) kadry prawnicze, tym bardziej praktyka administracji publicznej będzie realizować postulat "dobrej administracji”.

\section{Kilka słów o administracji publicznej}

W literaturze przedmiotu przyjmuje się, że administracja publiczna jest sprawowana przez państwo w najszerszym tego słowa znaczeniu, a więc zarówno przez organy państwowe, jak i związki publicznoprawne (związki samorządowe) i inne podmioty administracji ${ }^{9}$. Innymi słowy, „przez administrację publiczną rozumie się zespół działań, czynności i przedsięwzięć organizatorskich i wykonawczych, prowadzonych na rzecz realizacji interesu publicznego przez różne podmioty, organy i instytucje, na podstawie ustawy i w określonych prawem formach"10. Prezentując tytułowe rozważania na temat potrzeb polskiego sektora administracji publicznej w kontekście kształcenia prawniczego, przyjmuję powyższą, szeroką definicję administracji publicznej ${ }^{11}$. Pomimo takiego szerokiego ujęcia administracji publicznej nie należy zapominać, że model kształcenia prawniczego, który moglibyśmy określić jako pożądany czy oczekiwany, dotyczy także bezpośrednio sfery, która administracją publiczną nie jest, niemniej jest z nią ściśle związana. Chodzi tutaj przykładowo o sądownictwo administracyjne czy powszechne, które realizuje funkcje kontrolne wobec administracji publicznej. W sposób bezsprzeczny, co już zresztą sygnalizowałem wcześniej, dla prawidłowej realizacji tych funkcji niezbędne są właściwie wykształcone kadry prawnicze ${ }^{12}$. Wydaje się przy tym zasadne

\footnotetext{
8 K. Wojtyczek, Granice ingerencji ustawodawczej w sferę praw człowieka w Konstytucji RP, Kraków 1999, s. 136 i n.; D. Kijowski, Pozwolenia w administracji publicznej, Białystok 2000, s. 249 i n., cyt. za P. Żuradzki, op. cit.

$9 \quad$ E. Ochendowski, Prawo administracyjne. Część ogólna, Torun 2013, s. 22.

10 H. Izdebski, M. Kulesza, Administracja publiczna. Zagadnienia ogólne, Warszawa 1999, s. 79.

11 Por. S. Wrzosek, M. Kruszewska-Gagoś (red.), Prawo administracyjne, Lublin 2016, s. 17.

12 Zob. E. Gdulewicz (red.), Konstytucyjny system organów państwowych, Lublin 2015, s. 231 i n.
} 
stwierdzenie, że w znacznej części rolą prawnika działającego w strukturach administracji publicznej czy też poza nią, ale w związku, będzie stosowanie prawa administracyjnego, przy czym prawo to jako element prawa publicznego, w ślad za F. Wernerem, byłym prezesem Federalnego Sądu Administracyjnego RFN, „można potraktować jako prawo konstytucyjne w konkretnej formie"13.

\section{Projekt aplikacji uniwersyteckiej}

Pomysłów na zmiany i polepszenie kształcenia prawniczego jest wiele. Aktualnymi tego przejawami jest projekt aplikacji uniwersyteckiej. Pomysł aplikacji uniwersyteckiej, nazywanej też w dyskursie popularnonaukowym i publicystycznym "akademicką", jest młody i pojawił się szerzej w obiegu prasowym na początku 2018 r. Wskazywano wtedy, że „jeśli założenia przekształcą się w ustawę, niektóre z wyższych uczelni w kraju zyskają uprawnienie do kształcenia kandydatów na profesjonalnych pełnomocników. Niektóre, bo aplikacja uniwersytecka - jak się zastrzega - ma być elitarna. Poprowadzić ją będą mogły jedynie te jednostki, które dadzą rękojmię należytego przygotowania przyszłych aplikantów. Uzyskanie pozwolenia na ich kształcenie oparte ma być m.in. na kryteriach: liczby samodzielnych pracowników, liczby wpisanych na listę adwokatów i radców prawnych zatrudnionych na wydziale prawa, doświadczenia w kształceniu studentów, liczby absolwentów"14. Aplikacja akademicka według założeń ma być oparta na tutoringu, przy czym tutorem ma być adwokat lub radca prawny. Nauka na tej aplikacji miałaby trwać dwa lata, czyli o rok krócej aniżeli w przypadku aplikacji radcowskiej czy adwokackiej. Aktualnie, „sprawa poddawana jest wstępnej ocenie koncepcyjno-analitycznej"15 w resorcie sprawiedliwości, który patronuje projektowi aplikacji.

W niektórych środowiskach prawniczych projekt aplikacji został poddany krytyce. Przykładowo Prezydium Krajowej Rady Radców Prawnych wyraziło „zdecydowany sprzeciw”, wskazując m.in., że "projekt ten w istocie stanowi próbę wyprowadzenia aplikacji poza samorząd zawodowy"16. Podkreślono, że sprzeciw „budzi nadanie uprawnień „akademickim aplikantom prawniczym” do zastępowania radcy prawnego przed sądami, organami ścigania, organami państwowymi,

13 J. Jabłońska-Bonca, Podstawy prawa dla ekonomistów, Warszawa 2000, s. 367.

14 A. Krzyżanowska, Aplikacja akademicka - znamy założenia projektu, „Rzeczpospolita” 5.02.2018.

15 Eadem, Aplikacja akademicka: szumne zapowiedzi, działań brak, „Rzeczpospolita” 21.05.2018.

16 Stanowisko Prezydium Krajowej Rady Radców Prawnych w sprawie przedstawionych propozycji wprowadzenia tzw. aplikacji uniwersyteckiej z dnia 6 lutego 2018 r., opubl. na: http://kirp.pl/ stanowisko-prezydium-krajowej-rady-radcow-prawnych-sprawie-przedstawionych-propo zycji-wprowadzenia-tzw-aplikacji-uniwersyteckiej/ (dostęp: 16.07.2018). 
samorządowymi i innymi instytucjami, w sytuacji niezapewnienia obowiązku zachowania tajemnicy zawodowej oraz wyłączenia ich spod pieczy samorządu zawodowego"17. Rozwijając zarzuty wobec projektu, Z. Tur wskazuje, że „aplikacja ma przygotować aplikanta nie tylko do zdania egzaminu, ale nade wszystko do praktycznego, profesjonalnego wykonywania zawodu. Poprzestanie na tym pierwszym będzie dawało o sobie znać z każdym przegranym procesem, złą poradą, ludzkim nieszczęściem wynikającym nie ze złej woli, ale z braku praktyki"18. W dotychczasowym dyskursie nie odnalazłem stanowisk optujących "za” projektem.

Dokonując natomiast własnej oceny projektu aplikacji uniwersyteckiej, dołączam do grona jego krytyków, chociaż chcę zaakcentować swój sprzeciw wobec nadmiernego akcentowania praktycznego wymiaru studiowania, któremu niejednokrotnie nadaje się niewłaściwy, w moim przekonaniu, zakres.

\section{Mitologizowanie kształcenia praktycznego}

W polskim modelu kształcenia prawniczego wyróżnić można - oczywiście w uproszczeniu - dwa wymiary kształcenia: teoretyczny (naukowy, akademicki) i praktyczny.

Dążąc do optymalnego modelu kształcenia, a co za tym idzie, także realizacji postulatów dobrej administracji publicznej, nie należy wyłącznie skupiać się na aspekcie praktycznego studiowania i go akcentować ${ }^{19}$. Obserwowalne jest przy tym zjawisko, które nazywam "mitologizowaniem kształcenia praktycznego", polegające na przypisywaniu temu aspektowi kształcenia jedynej albo dominującej roli $\mathrm{w}$ procesie kształcenia in genere. Owe mitologizowanie jest też obserwowalne w kształceniu prawniczym i jest to moim zdaniem proces niepokojący. W Stowniku Języka Polskiego PWN czytamy, że mitologizowanie to „wprowadzanie do utworu elementów mitologicznych; przekształcanie czegoś w mit lub w legendę, tworzenie mitów wokół kogoś lub czegoss" 20 . Tak też się dzieje w przypadku przypisywania nadmiernego znaczenia kształceniu praktycznemu na kierunkach prawniczych; wokół owej praktyki wytwarza się niekiedy mit, o którym mowa wyżej. Poprzez

17 Ibidem.

18 Z. Tur, Aplikacja uniwersytecka: poczuć się radca, czyli doświadczenie nie dla każdego, „Rzeczpospolita” 16.07.2018.

19 Fraza "studiuj praktycznie" jest częstokroć motywem przewodnim kampanii reklamowych kierunków studiów czy też uczelni. Zaryzykuję stwierdzenie, że w polskim Internecie jest powszechna, czego dowodzi chociażby analiza wyników wyszukiwania po jej umieszczeniu w wyszukiwarce.

20 Stownik Języka Polskiego PWN, opubl. na: https:/sjp.pwn.pl/slowniki/mitologizowanie.html (dostęp: 16.07.2018). 
niewłaściwe proporcje i skupienie się wyłącznie albo dominująco na stronie praktycznej, sprowadza się kształcenie prawników do kształcenia rzemieślniczego, w negatywnym tego słowa znaczeniu. Tymczasem oprócz dobrego warsztatu rzemieślniczego, tj. praktycznego, prawnik powinien posiadać ugruntowaną wiedzę teoretyczną. Ta bowiem jest niezbędna dla właściwego zrozumienia i opisywania zjawisk towarzyszących pracy zawodowej m.in. w administracji publicznej. Niezbędna jest dla zrozumienia wartości o charakterze niematerialnym a ontologicznym, jak np. sprawiedliwość, słuszność. Wartości takie są fundamentem prawa rozumianego jako ars boni et aequi. Oczywiście nie można zaniedbywać sfery praktycznej, jest ona bowiem bardzo ważnym elementem kształcenia prawniczego. Niemniej zachodzi potrzeba jej umiejętnego zharmonizowania ze sferą teoretyczną, albowiem są one nierozerwalnie związane i wzajemnie skorelowane. Wyrażam przy tym przekonanie, że uczelnie posiadające uprawnienia do kształcenia na studiach prawniczych powinny skupić się na realizowaniu swojego głównego celu, a więc harmonijnego kształcenia, stosownie do zasad opisanych wyżej, o dychotomicznym charakterze praktyczno-teoretycznym.

Stąd też, powracając do krytyki projektu aplikacji uniwersyteckiej, na kanwie rozważań o mitologizowaniu kształcenia praktycznego w trakcie studiów prawniczych wyrażam przekonanie, że kształcenie aplikacyjne, mylnie przez niektórych komentatorów nazywane wyłącznie praktycznym (nie jest tak, kształcenie aplikacyjne ma realny wymiar teoretyczny), należałoby pozostawić w sferze korporacyjnej. „Szkoły wyższe realizują swoją misję, którą jest wszechstronne przygotowanie młodego prawnika do wyboru zawodowej (i życiowej w pewnym sensie) drogi. Miejsce aplikacji jest już po tym wyborze. Wtedy samorządy zawodowe nie mają dylematu i mogą przygotowywać aplikantów do konkretnych ról zawodowych: radcy prawnego czy adwokata. Wydziały prawa profesjonalnie opakowują wiedzę studenta i wyposażają go w możliwości wyboru zawodu, natomiast samorządy przygotowują prawnika do konkretnego zawodu"21. Pomimo, że nie podzielam w pełni przekonania o wyłącznym profesjonalizmie i wszechstronności w kształceniu prawniczym - te bowiem nie jest wolne od wad, to uważam jednak, że aktualny schemat kształcenia prawniczego - w kontekście sekwencji: uczelnia - aplikacja, jest dobry. Oczywiście aktualna i potrzebna jest krytyczna dyskusja nad zmianami zarówno w kształceniu uczelnianym, jak i aplikacyjnym, niemniej jest to tematyka na odrębne opracowania.

21 Z. Tur, op. cit. 


\section{Nowa ustawa i rozporządzenie - znaczenie dla kształcenia prawniczego}

Analizując projektowane rozwiązania, wydaje się, że ustawodawca dąży do realizacji nakreślonego wcześniej postulatu dychotomii teoretyczno-praktycznej w kształceniu prawniczym, chociaż nie wynika to wprost z treści ustawy. Szczególnej uwagi wymaga proponowany podział na uczelnie akademickie i zawodowe, stosownie do treści art. 14 i 15 u.p.s.w.in. Stanowią one, że uczelnia jest uczelnią akademicką, jeżeli prowadzi działalność naukową i posiada kategorię naukową A+, A albo B+ w co najmniej jednej dyscyplinie naukowej albo artystycznej. Z kolei uczelnia jest uczelnią zawodową, jeżeli prowadzi kształcenie uwzględniające potrzeby otoczenia społeczno-gospodarczego oraz nie spełnia warunku kategoryzacji naukowej. Konsekwencją przyjęcia uczelni za akademicką jest upoważnienie do prowadzenia studiów pierwszego i drugiego stopnia, jednolitych studiów magisterskich oraz kształcenia doktorantów. Uczelnia zawodowa z kolei prowadzi kształcenie na studiach wyłącznie o profilu praktycznym. Rozróżnienie studiów według profilu: praktyczny a ogólnoakademicki wiąże się natomiast z tym, że na profilu praktycznym ponad połowa punktów ECTS jest przypisana zajęciom kształtującym umiejętności praktyczne zaś na profilu ogólnoakademickim, ponad połowa punktów ECTS jest przypisana zajęciom związanym z prowadzoną w uczelni działalnością naukową.

Powyższa regulacja zawodowa ma istotne znaczenia w korelacji z treścią rozporządzenia, w którego § 7 ust. 1 wskazano, że kierunki studiów jak prawo, prawo kanoniczne - są prowadzone jako jednolite studia magisterskie. Stąd też kształcenie prawnicze będzie mogło odbywać się wyłącznie w uczelni akademickiej. Wyrażam przy tym nadzieję, że w dominującym zakresie zastosowanie znajdą w tym zakresie profile ogólnoakademickie, uwzględniające potrzeby edukacyjne o charakterze zarówno teoretycznym, jak i praktycznym. Warto przy tym wskazać, że w przypadku przyjęcia profilu praktycznego, stosownie do $\S 5$ rozporządzenia, zajęcia kształtujące umiejętności praktyczne są prowadzone w warunkach właściwych dla danego zakresu działalności zawodowej i w sposób umożliwiający wykonywanie czynności praktycznych przez studentów. A zatem wydaje się, że dla właściwej ich realizacji, charakterystycznej dla kształcenia prawniczego, uczelnia będzie musiała zapewnić „właściwe warunki”, przez co rozumiem np. sądową salę ćwiczeń czy laboratorium komputerowe z programem prawniczym. Projektowane zmiany oceniam pozytywnie i uważam, że jeżeli zostaną zrealizowane w praktyce uczelnianej, mogą przynieść pożądane rezultaty. 


\section{Podsumowanie}

Podsumowując, należy podkreślić, że polski sektor administracji publicznej wespół z działalnością mu towarzyszącą potrzebuje dobrze wykształconych kadr prawniczych, co wynika m.in. z potrzeby realizacji obywatelskiego prawa do dobrej administracji. Do kształcenia takich kadr mogą przyczynić się projektowane zmiany, zawarte w ustawie 2.0 i rozporządzeniu w sprawie studiów. Jednak z uwagi na szeroką autonomię uczelni i swobodę, jaką daje ustawa, praktyczna realizacja tego kształcenia będzie zależała od zaangażowania poszczególnych uczelni. Istotnym zagadnieniem będzie tutaj w moim przekonaniu nie mitologizowanie kształcenia praktycznego i wypracowanie wyważonego programu kształcenia uwzględniającego także aspekt stricte naukowy, teoretyczny. Jednoznacznie negatywnie należy przy tym ocenić projekt aplikacji uniwersyteckiej, jako zbędny i niecelowy. Stąd też ostatecznie podsumowując, chciałbym sięgnąć do nieco patetycznego, ale pasującego do tematyki tekstu - cytatu Jana Zamoyskiego z aktu fundacyjnego Akademii Zamojskiej z 1600 r.: „takie będą Rzeczypospolite, jakie ich młodzieży chowanie”; rzeczywiście, kształt polskiego sektora administracji publicznej będzie zależał od prawniczego „chowania” w tym zakresie.

\section{Bibliografia}

Gdulewicz E. (red.), Konstytucyjny system organów państwowych, Lublin 2015.

Izdebski H., Kulesza M., Administracja publiczna. Zagadnienia ogólne, Warszawa 1999.

Jabłońska-Bonca J., Podstawy prawa dla ekonomistów, Warszawa 2000.

Kijowski D., Pozwolenia w administracji publicznej, Białystok 2000.

Krzyżanowska A., Aplikacja akademicka - znamy założenia projektu, „Rzeczpospolita” 5.02.2018.

Krzyżanowska A., Aplikacja akademicka: szumne zapowiedzi, działań brak, „Rzeczpospolita” 21.05.2018.

Ochendowski E., Prawo administracyjne. Część ogólna, Torun 2013.

Stownik Języka Polskiego PWN, https://sjp.pwn.pl/slowniki/mitologizowanie.html (dostęp: 16.07.2018).

Tur Z., Aplikacja uniwersytecka: poczuć się radca, czyli doświadczenie nie dla każdego, „Rzeczpospolita" 16.07.2018.

Wojtyczek K., Granice ingerencji ustawodawczej w sferę praw człowieka w Konstytucji RP, Kraków 1999.

Wrzosek S., Kruszewska-Gagoś M. (red.), Prawo administracyjne, Lublin 2016.

Żuradzki P., Prawo do dobrej administracji w polskim porządku prawnym na tle Europejskiego kodeksu dobrej administracji, [w:] M. Kępa. M. Marszał (red.), Duch praw w krajach Europy Środkowo-Wschodniej, Wrocław 2016. 